\title{
Studies on Assessing the Biochemical and Morphological Changes in Eucalyptus sp Clones under Elevated Carbon-di-oxide
}

\author{
M.P. Sugumaran ${ }^{1}$, Kudimetha Ganesh Kumar $^{1}$ and C. Buvaneswaran ${ }^{2}$ \\ ${ }^{1}$ Department of Environmental Sciences, Tamil Nadu Agricultural University, \\ Coimbatore, India \\ ${ }^{2}$ Institute of Forest Genetics and Tree Breeding (IFGTB), Coimbatore, India \\ *Corresponding author
}

\section{Keywords \\ Elevated $\mathrm{CO}_{2}$, Automated open top chambers, Morphological changes, Biochemical changes \\ Article Info \\ Accepted: \\ 10 April 2019 \\ Available Online: \\ 10 May 2019}

\section{A B S T R A C T}

This paper discusses about the biochemical and morphological changes in Eucalyptus sp clones to elevated $\mathrm{CO}_{2}$ conditions in AOTC (Automated Open Top Chambers). In this study, three months old clones of Eucalyptus sp were exposed to elevated $\mathrm{CO}_{2}$ levels in open top chambers at $900 \mathrm{ppm}$ and $600 \mathrm{ppm}$ for a period of four months. In Eucalyptus sp clones, the highest values of chlorophyll was recorded by the clone I (39.48) and the lowest values of chlorophyll (26.70) is recorded in clone $\mathrm{V}$ in ambient conditions for Eucalyptus sp after four months. The clonal mean was high (36.73) in clone I and treatment mean was high (38.33) in chamber control. The shoot fresh weight was high in clone III $(29.32 \mathrm{~g})$ in ambient conditions and the lower shoot fresh weight was reported in clone IV $(9.07 \mathrm{~g})$ in chamber control. Clonal mean was high in clone III $(27.31 \mathrm{~g})$ and treatment mean was high (18.52 g) in ambient conditions. Leaf fresh weight was registered high in clone III (33.42 g) in $900 \mathrm{ppm}$ elevated $\mathrm{CO}_{2}$ levels and the lower leaf fresh weight was reported in the clone IV (15.02 g) in chamber control. Root fresh weight was high in clone II (13 g) under $900 \mathrm{ppm}$ elevated $\mathrm{CO}_{2}$ and the lower root fresh weight was recorded by the clone I $(5.04 \mathrm{~g})$. The clonal mean was high in clone IV $(9.17 \mathrm{~g})$ and the treatment mean was high in ambient conditions $(8.92 \mathrm{~g})$. This study concludes that there is an intraspecific variation in Eucalyptus sp, which can be utilized for future breeding programmes to develop genotypes that withstand the changing climatic conditions.

\section{Introduction}

Global warming plays a major role in climate change that is mainly caused by the increase of atmospheric carbon dioxide $\left(\mathrm{CO}_{2}\right)$ and other green house gases (GHGs) such as methane $\left(\mathrm{CH}_{4}\right)$, nitrous oxide $\left(\mathrm{N}_{2} \mathrm{O}\right)$ and Chlorofluoro Carbon (CFC) level in the last two decades. These greenhouse gases partially absorb long wave radiation remitted by the earth's warm surface and re-emit the same resulting in warming up in the atmosphere. Studies on carbon enrichment with special chambers will leads to understanding the response of tree species at individual level through morphological, physiological and biochemical traits. Growth rates usually accelerate when terrestrial plants 
are grown in elevated $\mathrm{CO}_{2}$ levels. The plant mean growth rate, number of leaf productions under elevated $\mathrm{CO}_{2}$ levels will alter the morphology of particular species. The tropical plants show alterations in morphology and biomass and distribution due to the growth in elevated $\mathrm{CO}_{2}$ concentration. Elevated $\mathrm{CO}_{2}$ is a tool that can be used to modify growth and resource allocation in tree species.

\section{Materials and Methods}

\section{Location}

The experiment was conducted in silviculture nursery of Institute of Forest Genetics and Tree Breeding at Coimbatore at $11^{0} 59^{\prime} 01.69^{\prime \prime} \mathrm{N}, 76^{0} 57^{\prime} 25.32^{\prime \prime} \mathrm{E}$ and $437 \mathrm{~m}$ from mean sea level.

Experiment site experiences the maximum temperature $44^{\circ} \mathrm{C}$ and minimum temperature $36{ }^{0} \mathrm{C}$, average annual rainfall $315 \mathrm{~mm}$ and relative humidity $77 \%$.

\section{Automated open top chambers}

Open top chambers are widely used for exposing plants to elevated levels of $\mathrm{CO}_{2}$ and other gases besides simulated humidity and temperature. The OTCs are transparent chambers open at top in which $\mathrm{CO}_{2}$ is pumped at the bottom to maintain the desired levels. The AOTC has recent developments with fully automated control and monitoring system.

\section{Structure of AOTCs}

The chambers were cubical type structure of $3 \times 3 \times 3 \mathrm{~m}$ dimensions, fabricated with galvanized iron pipe frames. The structures were covered with UV protected polyvinyl chloride sheet of $120 \mu$ thickness in order to have a transmittance of more than $95 \%$ of ambient radiation. The upper portion of the chamber was kept open to maintain near natural condition.

\section{Experiment setup}

$\mathrm{T}_{1}$ : Ambient

$\mathrm{T}_{2}$ : Chamber Control

$\mathrm{T}_{3}: \mathrm{CO}_{2} @ 600$ ppm

$\mathrm{T}_{4}: \mathrm{CO}_{2} @ 900 \mathrm{ppm}$

Factors: Plant, $\mathrm{CO}_{2}$

Clones: 5

\section{Plant details}

Clones

PS-I- (ITC-ECEU-1)

PS-II- (ITC-EUEC-2)

PS-III-(EGEC-3)

PS-IV-(ECEC-4)

PS-V-(CTCC-5)

Design: FCRD

Replications: 10

Duration: 120 days

Date of start of experiment: 30.11.2017

\section{Chlorophyll content}

Chlorophyll content was recorded using a portable chlorophyll meter (Minolta SPAD 502) at the 30 and 40 days after installing. The Minolta SPAD-502 measures chlorophyll content as ratio of transmittance of light at wavelength of $650 \mathrm{~nm}$ and $940 \mathrm{~nm}$. Three readings were taken from each replication and the average values were computed using the method described by Monje and Bugbee (1998).

\section{Morphological observation}

Morphological observations like plant height, number of leaves per plant, collar diameter was recorded once in a week. After the end of the experiment (4 months), the plants were uprooted and fresh and dry weights of shoot, leaves and root was observed. 


\section{Results and Discussion}

\section{Chlorophyll content}

The highest value of chlorophyll in Eucalyptus sp was recorded in the clone I (36.39) in chamber control and the lowest value is recorded by the clone II (25.23) in ambient conditions. The clonal mean was highest (32.09) in clone I and the treatment mean was high in chamber control (34.79) at the time of transplanting the seedlings in pots. The values are not significant after 2 months after the experiment and highest value was recorded in clone $\mathrm{V}$ in $600 \mathrm{ppm}$ (37.60) and the lowest value was recorded by the clone I (30.52) in ambient conditions.

The highest values of chlorophyll were recorded by the clone I (39.48) and the lowest values of chlorophyll (26.70) are recorded in clone $\mathrm{V}$ in ambient conditions for Eucalyptus sp after four months. The clonal mean was high (36.73) in clone I and treatment mean was high (38.33) in chamber control (Table 1).

In the present study, significant increase of chlorophyll content in five clones of Eucalyptus sp was observed under elevated $\mathrm{CO}_{2}$ environment. Generally chlorophyll content was increased in matured leaves of tree species when they are exposed to elevated $\mathrm{CO}_{2}$ and was reported by Saravanan and Karthi (2014). Similar finding were reported in radish which indicates two fold increase of chlorophyll concentration at higher levels of $\mathrm{CO} 2$ conditions.

\section{Shoot weight}

The shoot fresh weight was high in clone III $(29.32 \mathrm{~g})$ in ambient conditions and the lower shoot fresh weight was reported in clone IV $(9.07 \mathrm{~g})$ in chamber control. Clonal mean was high in clone III (27.31 g) and treatment mean was high (18.52 g) in ambient conditions (Table 2). There is no significant difference in terms of shoot dry weight for all the clones except clone III which has shown significant variation.

The highest mean value of shoot dry weight was reported by the clone II (8.62 g) and the lowest value of shoot dry weight was observed in the clone IV (3.18 g). The clonal mean was maximum in clone $\mathrm{V}(8.92 \mathrm{~g})$ which indicates clone $\mathrm{V}$ has best performance under elevated $\mathrm{CO}_{2}$. The treatment average was high in ambient condition (11.39 g) (Table 3).

\section{Leaf weight}

Leaf fresh weight was registered high in clone III (33.42 g) in 900 ppm elevated $\mathrm{CO}_{2}$ levels and the lower leaf fresh weight was reported in the clone IV (15.02 g) in chamber control. Clonal mean was high in clone III (29.49 g) and the treatment mean was high in $900 \mathrm{ppm}$ chamber (25.49g) (Table 4). Leaf dry weight was reported to be high in clone III (18.66 g).

The lowest value was reported by the clone IV $(6.67 \mathrm{~g})$. The clonal mean was reported high in clone III (17.20 g), treatment mean value was high in $600 \mathrm{ppm}$ elevated $\mathrm{CO}_{2}$ (14.46 g) (Table 5).

The current investigation in Eucalyptus seedlings under elevated $\mathrm{CO}_{2}$ level registered an increase in weight of fresh and dry weight of leaves compared to ambient conditions. Similar to this, there was $37 \%$ increase in SLW (specific leaf weight) under elevated $\mathrm{CO}_{2}$ levels in soyabean. Moreover, it was shown that, when Populus trichocarpa grown in elevated $\mathrm{CO}_{2}$ levels produced thicker leaves and a greater leaf weight per unit leaf area over ambient conditions (Radoglou and Jarvis, 1990). 
Table.1 Chlorophyll content (using SPAD) after 4 months in Eucalyptus sp clones under different $\mathrm{CO}_{2}$ levels in open top chambers

\begin{tabular}{|c|c|c|c|c|c|c|}
\hline \multirow[t]{2}{*}{ Treatments } & \multicolumn{5}{|c|}{ Plant source } & \multirow[t]{2}{*}{ Treatment mean } \\
\hline & $\mathbf{I}$ & II & III & IV & $\mathbf{V}$ & \\
\hline Ambient & $31.56 \pm 1.05^{\mathrm{b}}$ & $30.69 \pm 1.31^{b}$ & $28.77 \pm 1.56^{\mathrm{b}}$ & $28.32 \pm 0.76^{b}$ & $26.70 \pm 1.35^{\mathrm{b}}$ & 29.20 \\
\hline Chamber control & $39.48 \pm 2.30^{\mathrm{a}}$ & $36.71 \pm 2.32^{\mathrm{a}}$ & $39.29 \pm 2.41^{\mathrm{a}}$ & $37.89 \pm 2.06^{\mathrm{a}}$ & $38.31 \pm 2.17^{\mathrm{a}}$ & 38.33 \\
\hline 600 ppm & $38.79 \pm 1.75^{\mathrm{a}}$ & $34.44 \pm 0.94^{\mathrm{a}}$ & $33.36 \pm 1.97^{\mathrm{b}}$ & $32.49 \pm 2.00^{\mathrm{b}}$ & $30.91 \pm 1.67^{b}$ & 33.99 \\
\hline 900 ppm & $37.10 \pm 2.45^{b}$ & $35.06 \pm 2.03^{\mathrm{a}}$ & $37.77 \pm 2.25^{\mathrm{a}}$ & $36.82 \pm 2.14^{\mathrm{a}}$ & $36.72 \pm 1.96^{\mathrm{a}}$ & 36.69 \\
\hline Clone mean & 36.73 & 34.44 & 34.79 & 33.88 & 33.16 & 34.55 \\
\hline$P$ value & $\mathbf{0 . 0 3 0}$ & 0.124 & 0.004 & 0.003 & 0.000 & \\
\hline
\end{tabular}

\pm : Standard Error, Values followed by same letters with in columns are not significantly difference at $\mathrm{P} \leq 0.05$

Table.2 Shoot fresh weight (gm) of eucalyptus clones under different $\mathrm{CO}_{2}$ levels in open top chambers

\begin{tabular}{|c|c|c|c|c|c|c|}
\hline \multirow[t]{2}{*}{ Treatments } & \multicolumn{5}{|c|}{ Plant source } & \multirow[t]{2}{*}{ Treatment mean } \\
\hline & I & II & III & IV & $\mathbf{V}$ & \\
\hline Ambient & $13.24 \pm 1.02^{\mathrm{a}}$ & $18.58 \pm 1.45^{b}$ & $29.32 \pm 1.68^{\mathrm{a}}$ & $12.87 \pm 0.98^{\mathrm{a}}$ & $18.59 \pm 1.41^{\mathrm{a}}$ & 18.52 \\
\hline Chamber control & $14.42 \pm 1.81^{\mathrm{a}}$ & $14.45 \pm 0.92^{\mathrm{c}}$ & $26.00 \pm 1.50^{\mathrm{a}}$ & $9.07 \pm 1.30^{\mathrm{a}}$ & $19.54 \pm 1.06^{\mathrm{a}}$ & 16.70 \\
\hline $600 \mathrm{ppm}$ & $13.64 \pm 0.79^{\mathrm{a}}$ & $21.02 \pm 0.88^{\mathrm{a}}$ & $25.35 \pm 1.88^{\mathrm{a}}$ & $13.13 \pm 1.01^{\mathrm{a}}$ & $13.51 \pm 2.17^{b}$ & 17.33 \\
\hline 900 ppm & $12.08 \pm 1.02^{\mathrm{a}}$ & $22.50 \pm 0.62^{\mathrm{a}}$ & $28.58 \pm 1.17^{\mathrm{a}}$ & $10.69 \pm 0.68^{\mathrm{a}}$ & $12.78 \pm 1.24^{b}$ & 17.32 \\
\hline Clone mean & 13.34 & 19.14 & 27.31 & 11.44 & 16.10 & 17.47 \\
\hline$P$ value & 0.405 & 0.000 & 0.234 & 0.392 & 0.005 & \\
\hline
\end{tabular}

\pm : Standard Error, Values followed by same letters with in columns are not significantly difference at $\mathrm{P} \leq 0.05$ 
Table.3 Shoot dry weight (gm) of eucalyptus clones under different $\mathrm{CO}_{2}$ levels in open top chambers

\begin{tabular}{|c|c|c|c|c|c|c|}
\hline \multirow[t]{2}{*}{ Treatments } & \multicolumn{5}{|c|}{ Plant source } & \multirow[t]{2}{*}{ Treatment mean } \\
\hline & I & II & III & IV & V & \\
\hline Ambient & $5.38 \pm 0.77^{\mathrm{a}}$ & $4.56 \pm 0.71^{b}$ & $6.6 \pm 0.89^{\mathrm{a}}$ & $5.98 \pm 0.70^{\mathrm{a}}$ & $8.21 \pm 0.79^{\mathrm{a}}$ & 6.16 \\
\hline Chamber control & $4.88 \pm 0.59^{\mathrm{a}}$ & $5.12 \pm 0.64^{b}$ & $5.10 \pm 0.61^{\mathrm{a}}$ & $4.13 \pm 0.40^{b}$ & $10.03 \pm 1.13^{\mathrm{a}}$ & 5.85 \\
\hline 600 ppm & $4.41 \pm 0.69^{\mathrm{ba}}$ & $3.78 \pm 0.71^{b}$ & $4.74 \pm 0.42^{\mathrm{a}}$ & $3.18 \pm 0.67^{b}$ & $8.84 \pm 0.74^{\mathrm{a}}$ & 4.99 \\
\hline 900 ppm & $2.96 \pm 0.36^{b}$ & $8.62 \pm 1.40^{\mathrm{a}}$ & $4.83 \pm 0.62^{\mathrm{a}}$ & $4.87 \pm 0.40^{\mathrm{ba}}$ & $8.62 \pm 0.87^{\mathrm{a}}$ & 5.98 \\
\hline Clone mean & 4.41 & 5.52 & 5.34 & 4.54 & 8.92 & 5.75 \\
\hline$P$ value & 0.054 & 0.004 & 0.147 & 0.10 & 0.525 & \\
\hline
\end{tabular}

\pm : Standard Error, Values followed by same letters with in columns are not significantly difference at $\mathrm{P} \leq 0.05$

Table.4 Leaf fresh weight (gm) of eucalyptus clones under different $\mathrm{CO}_{2}$ levels in open top chambers

\begin{tabular}{|c|c|c|c|c|c|c|}
\hline \multirow[t]{2}{*}{ Treatments } & \multicolumn{5}{|c|}{ Plant source } & \multirow[t]{2}{*}{ Treatment mean } \\
\hline & I & II & III & IV & $\mathbf{V}$ & \\
\hline Ambient & $24.18 \pm 2.67^{\mathrm{a}}$ & $18.01 \pm 3.02^{b}$ & $30.60 \pm 1.42^{\mathrm{ba}}$ & $25.01 \pm 1.12^{\mathrm{a}}$ & $25.51 \pm 2.25^{\mathrm{a}}$ & 24.66 \\
\hline Chamber control & $23.12 \pm 1.04^{\mathrm{a}}$ & $22.46 \pm 0.79^{b}$ & $23.59 \pm 3.98^{b}$ & $15.02 \pm 2.43^{b}$ & $26.74 \pm 0.99^{\mathrm{a}}$ & 22.18 \\
\hline 600 ppm & $21.30 \pm 1.49^{\mathrm{a}}$ & $28.65 \pm 0.78^{\mathrm{a}}$ & $30.36 \pm 1.77^{\mathrm{a}}$ & $21.73 \pm 1.36^{\mathrm{a}}$ & $18.08 \pm 3.13^{b}$ & 24.03 \\
\hline 900 ppm & $23.07 \pm 1.61^{\mathrm{a}}$ & $29.95 \pm 1.01^{\mathrm{a}}$ & $33.42 \pm 2.07^{\mathrm{a}}$ & $22.45 \pm 1.08^{\mathrm{a}}$ & $18.57 \pm 1.75^{b}$ & 25.49 \\
\hline Clone mean & 22.92 & 24.77 & 29.49 & 21.05 & 22.22 & 24.09 \\
\hline$P$ value & 0.729 & 0.000 & 0.057 & 0.001 & 0.010 & \\
\hline
\end{tabular}

\pm : Standard Error, Values followed by same letters with in columns are not significantly difference at $\mathrm{P} \leq 0.05$ 
Table.5 Leaf dry weight (gm) of eucalyptus clones under different $\mathrm{CO}_{2}$ levels in open top chambers

\begin{tabular}{|c|c|c|c|c|c|c|}
\hline \multirow[t]{2}{*}{ Treatments } & \multicolumn{5}{|c|}{ Plant source } & \multirow[t]{2}{*}{ Treatment mean } \\
\hline & $\mathbf{I}$ & II & III & IV & $\mathbf{V}$ & \\
\hline Ambient & $14.99 \pm 1.25^{\mathrm{a}}$ & $11.68 \pm 2.34^{\mathrm{c}}$ & $18.66 \pm 0.90^{\mathrm{a}}$ & $9.64 \pm 0.72^{\mathrm{a}}$ & $14.06 \pm 1.59^{\mathrm{a}}$ & 13.81 \\
\hline Chamber control & $16.02 \pm 0.94^{\mathrm{a}}$ & $21.86 \pm 0.79^{\mathrm{a}}$ & $15.27 \pm 1.99^{\mathrm{a}}$ & $7.42 \pm 1.23^{\mathrm{ba}}$ & $9.36 \pm 1.66^{\mathrm{b}}$ & 13.98 \\
\hline 600 ppm & $14.60 \pm 0.95^{\mathrm{a}}$ & $17.50 \pm 0.67^{b}$ & $16.57 \pm 1.34^{\mathrm{a}}$ & $9.69 \pm 0.48^{\mathrm{a}}$ & $13.95 \pm 1.26^{\mathrm{a}}$ & 14.46 \\
\hline 900 ppm & $12.73 \pm 1.12^{\mathrm{a}}$ & $14.49 \pm 1.07^{\mathrm{cb}}$ & $18.30 \pm 1.54^{\mathrm{a}}$ & $6.67 \pm 0.74^{b}$ & $9.45 \pm 1.05^{\mathrm{b}}$ & 12.33 \\
\hline Clone mean & 14.58 & 16.38 & 17.20 & 8.35 & 11.71 & 13.65 \\
\hline$P$ value & 0.199 & 0.000 & 0.358 & 0.029 & 0.025 & \\
\hline
\end{tabular}

士: Standard Error, Values followed by same letters with in columns are not significantly difference at $\mathrm{P} \leq 0.05$

Table.6 Root fresh weight (gm) of eucalyptus clones under different $\mathrm{CO}_{2}$ levels in open top chambers

\begin{tabular}{|c|c|c|c|c|c|c|}
\hline \multirow[t]{2}{*}{ Treatments } & \multicolumn{5}{|c|}{ Plant Source } & \multirow[t]{2}{*}{ Treatment mean } \\
\hline & I & II & III & IV & $\mathbf{V}$ & \\
\hline Ambient & $9.08 \pm 1.14^{\mathrm{a}}$ & $7.15 \pm 1.07^{\mathrm{b}}$ & $11.41 \pm 1.53^{\mathrm{a}}$ & $11.67 \pm 1.07^{\mathrm{a}}$ & $5.29 \pm 0.411^{\mathrm{b}}$ & 8.92 \\
\hline Chamber control & $7.99 \pm 0.62^{\mathrm{a}}$ & $6.52 \pm 0.94^{\mathrm{b}}$ & $8.89 \pm 0.95^{\mathrm{ba}}$ & $5.67 \pm 0.97^{\mathrm{b}}$ & $7.73 \pm 0.74^{\mathrm{a}}$ & 7.36 \\
\hline $600 \mathrm{ppm}$ & $6.94 \pm 0.87^{\mathrm{ba}}$ & $8.67 \pm 0.75^{b}$ & $7.54 \pm 0.80^{b}$ & $9.66 \pm 0.65^{\mathrm{a}}$ & $5.57 \pm 0.76^{\mathrm{b}}$ & 7.68 \\
\hline 900 ppm & $5.04 \pm 0.50 \mathrm{~b}$ & $13.00 \pm 1.63 \mathrm{a}$ & $8.71 \pm 0.74^{\mathrm{ba}}$ & $9.65 \pm 0.85^{\mathrm{a}}$ & $4.78 \pm 0.66^{b}$ & 8.24 \\
\hline Clone mean & 7.26 & 8.83 & 9.14 & 9.17 & 5.84 & 8.05 \\
\hline$P$ value & 0.010 & 0.001 & 0.086 & 0.000 & 0.017 & \\
\hline
\end{tabular}

\pm : Standard Error, Values followed by same letters with in columns are not significantly difference at $\mathrm{P} \leq 0.05$ 
Table.7 Root dry weight (gm) of eucalyptus clones under different $\mathrm{CO}_{2}$ levels in open top chambers

\begin{tabular}{|c|c|c|c|c|c|c|}
\hline \multirow[t]{2}{*}{ Treatments } & \multicolumn{5}{|c|}{ Plant source } & \multirow[t]{2}{*}{ Treatment mean } \\
\hline & $\mathbf{I}$ & II & III & IV & $\mathbf{V}$ & \\
\hline Ambient & $6.52 \pm 0.66^{\mathrm{a}}$ & $18.51 \pm 1.35^{\mathrm{a}}$ & $12.99 \pm 1.21^{b}$ & $7.31 \pm 1.17^{\mathrm{a}}$ & $11.64 \pm 0.76^{\mathrm{a}}$ & $\begin{array}{c}11.3 \\
9\end{array}$ \\
\hline Chamber control & $6.20 \pm 1.14^{\mathrm{a}}$ & $15.22 \pm 1.12^{\mathrm{a}}$ & $15.76 \pm 1.08^{\mathrm{a}}$ & $5.78 \pm 0.58^{\mathrm{a}}$ & $10.67 \pm 0.87^{\mathrm{a}}$ & $\begin{array}{c}10.7 \\
2\end{array}$ \\
\hline 600 ppm & $4.98 \pm 0.85^{\mathrm{a}}$ & $16.02 \pm 1.50^{\mathrm{a}}$ & $9.71 \pm 0.64^{\mathrm{c}}$ & $4.83 \pm 0.74^{\mathrm{a}}$ & $9.54 \pm 2.12^{\mathrm{a}}$ & 9.02 \\
\hline 900 ppm & $6.60 \pm 1.15^{\mathrm{a}}$ & $15.72 \pm 1.05^{\mathrm{a}}$ & $11.66 \pm 0.77^{\mathrm{cb}}$ & $6.39 \pm 16^{\mathrm{a}}$ & $12.64 \pm 1.18^{\mathrm{a}}$ & $\begin{array}{c}10.6 \\
0\end{array}$ \\
\hline Clone mean & 6.08 & 16.37 & 12.53 & 6.08 & 11.12 & $\begin{array}{c}10.4 \\
3\end{array}$ \\
\hline$P$ value & 0.626 & 0.280 & 0.001 & 0.322 & 0.420 & \\
\hline
\end{tabular}

\pm : Standard Error, Values followed by same letters with in columns are not significantly difference at $\mathrm{P} \leq 0.05$

Table.8 Number of primary roots in Eucalyptus sp clones (in 4 months) under different $\mathrm{CO}_{2}$ levels in open top chambers

\begin{tabular}{|c|c|c|c|c|c|c|}
\hline \multirow[t]{2}{*}{ Treatments } & \multicolumn{5}{|c|}{ Plant source } & \multirow[t]{2}{*}{ Treatment mean } \\
\hline & I & II & III & IV & $\mathbf{V}$ & \\
\hline Ambient & $5.70 \pm 0.55^{\mathrm{a}}$ & $5.90 \pm 0.54^{b}$ & $9.00 \pm 0.57^{\mathrm{a}}$ & $9.80 \pm 0.89^{\mathrm{a}}$ & $5.10 \pm 0.70^{b}$ & 7.10 \\
\hline Chamber control & $4.60 \pm 0.65^{\mathrm{ab}}$ & $4.70 \pm 0.44^{b}$ & $8.20 \pm 0.69^{\mathrm{a}}$ & $4.40 \pm 2.22^{\mathrm{b}}$ & $7.40 \pm 0.33^{\mathrm{a}}$ & 5.86 \\
\hline 600 ppm & $5.60 \pm 0.42^{\mathrm{a}}$ & $5.60 \pm 0.66^{b}$ & $7.50 \pm 0.68^{\mathrm{a}}$ & $10.10 \pm 0.88^{\mathrm{a}}$ & $4.20 \pm 0.62^{b}$ & 6.60 \\
\hline 900 ppm & $3.70 \pm 0.55^{b}$ & $8.60 \pm 0.97^{\mathrm{a}}$ & $8.00 \pm 0.95^{\mathrm{a}}$ & $12.40 \pm 1.56^{\mathrm{a}}$ & $4.80 \pm 0.62^{b}$ & 7.50 \\
\hline Clone mean & 4.90 & 6.20 & 8.18 & 9.18 & 5.38 & 6.77 \\
\hline$P$ value & 0.049 & 0.002 & 0.554 & 0.000 & 0.003 & \\
\hline
\end{tabular}

\pm : Standard Error, Values followed by same letters with in columns are not significantly difference at $\mathrm{P} \leq 0.05$ 
Table.9 Number of secondary roots in Eucalyptus sp clones (in 4 months) under different $\mathrm{CO}_{2}$ levels in open top chambers

\begin{tabular}{|c|c|c|c|c|c|c|}
\hline \multirow[t]{2}{*}{ Treatments } & \multicolumn{5}{|c|}{ Plant source } & \multirow[t]{2}{*}{ Treatment mean } \\
\hline & $\mathbf{I}$ & II & III & IV & V & \\
\hline Ambient & $28.70 \pm 2.13^{\mathrm{ab}}$ & $29.20 \pm 2.86^{b}$ & $40.60 \pm 4.56^{\mathrm{a}}$ & $57.80 \pm 2.45^{\mathrm{a}}$ & $26.10 \pm 1.33^{b}$ & 36.48 \\
\hline Chamber control & $31.40 \pm 1.88^{\mathrm{a}}$ & $33.40 \pm 4.26^{\mathrm{ba}}$ & $32.10 \pm 2.33^{\mathrm{a}}$ & $20.50 \pm 1.47^{\mathrm{c}}$ & $38.30 \pm 2.88^{\mathrm{a}}$ & 31.14 \\
\hline 600 ppm & $23.50 \pm 1.68^{b}$ & $32.10 \pm 3.08^{\mathrm{ba}}$ & $33.40 \pm 2.06^{\mathrm{a}}$ & $44.20 \pm 4.71^{b}$ & $22.30 \pm 1.89^{b}$ & 31.10 \\
\hline 900 ppm & $27.90 \pm 3.65^{\mathrm{ab}}$ & $40.10 \pm 2.19^{\mathrm{a}}$ & $32.70 \pm 2.65^{\mathrm{a}}$ & $49.20 \pm 4.62^{b a}$ & $28.90 \pm 4.05^{b}$ & 35.76 \\
\hline Clone mean & 27.88 & 33.70 & 34.70 & 42.93 & 28.90 & 33.62 \\
\hline$P$ value & 0.171 & 0.118 & 0.189 & 0.000 & 0.002 & \\
\hline
\end{tabular}

士: Standard Error, Values followed by same letters with in columns are not significantly difference at $\mathrm{P} \leq 0.05$ 


\section{Root weight}

Root fresh weight was high in clone II (13 g) under 900 ppm elevated $\mathrm{CO}_{2}$ and the lower root fresh weight was recorded by the clone I $(5.04 \mathrm{~g})$. The clonal mean was high in clone IV $(9.17 \mathrm{~g})$ and the treatment mean was high in ambient conditions (8.92g) (Table 6).

In current investigation of eucalyptus under elevated $\mathrm{CO}_{2}$ conditions root dry weight was calculated and the higher value of root dry weight was reported by the clone V (12.64 g) in $900 \mathrm{ppm}$. The lowest value was reported by the clone IV (4.18 g) in $600 \mathrm{ppm}$ treatment. The clonal mean of root dry weight was high in clone II $(16.37 \mathrm{~g})$, the treatment mean of root dry weight was highest in ambient conditions (11.39 g) (Table 7).

\section{Primary roots}

In the current investigation, the number of primary and secondary root production was varied in all the 5 clones of Eucalyptus under different levels of $\mathrm{CO}_{2}$ exposure inside the automated open top chambers. The highest number of primary roots was observed in Clone IV (12.4) in $900 \mathrm{ppm}$ and the lowest value of primary root is recorded in clone $\mathrm{V}$ (4.2) in 600 ppm chamber.

The clonal mean was high in Clone IV (9.18) and in treatment mean the $900 \mathrm{ppm}$ recorded higher mean value (7.5) (Table 8).

\section{Secondary roots}

Eucalyptus sp clones were observed for the secondary root variations and the higher values of secondary root was observed in clone IV
(57.8) in ambient conditions and the lower values were recorded in $600 \mathrm{ppm}$ chamber (22.3).

The clonal mean value was high in clone IV (42.93) and the treatment mean was higher in ambient conditions (36.48) (Table 9).

In conclusion, from the present study, we came to know that there is an intra specific variation among the clones (based on biochemical changes and morphological changes), so the best suitable clones are experimented further for getting more adaptable varieties for the changing climatic conditions.

\section{Acknowledgement}

The authors heartfully thank the officials of Forest Genetics and Tree Breeding, Coimbatore for helping to utilize the Open Top Chambers and other instruments to conduct this study.

\section{References}

Monje, O., and Bugbee, B. (1998). Adaptation to high $\mathrm{CO}_{2}$ concentration in an optimal environment: radiation capture, canopy quantum yield and carbon use efficiency. Plant, Cell and Environment, 21(3), 315324.

Saravanan, S., and Karthi, S. (2014). HPLC Analysis for Methanolic Extract of Catharanthus roseus under Elevated $\mathrm{CO}_{2}$. World Journal of Pharmacy and Pharmaceutical Sciences, 3(10), 683693.

Radoglou and Jarvis. 1990. Effects of $\mathrm{CO}_{2}$ enrichment on four poplar clones II leaf surface properties. Annals of Botany. 65(6): $627-632$

\section{How to cite this article:}

Sugumaran, M.P., Kudimetha Ganesh Kumar and Buvaneswaran, C. 2019. Studies on Assessing the Biochemical and Morphological Changes in Eucalyptus sp Clones under Elevated Carbon-dioxide. Int.J.Curr.Microbiol.App.Sci. 8(05): 784-792. doi: https://doi.org/10.20546/ijcmas.2019.805.093 